\title{
Studia
}

SYNCHRONICZNE I DIACHRONICZNE ASPEKTY BADAŃ POLSZCZYZNY

www.wnus.edu.pl/sj | DOI: 10.18276/sj.2019.18-05 | 55-74

ANDRZEJ S. DYSZAK

ORCID: 0000-0002-2054-1192

Uniwersytet Kazimierza Wielkiego, Bydgoszcz

dyszak@ukw.edu.pl

\section{Językowe środki neutralizacji śmierci w listach Jarosława Iwaszkiewicza do zmarłego Jerzego Błeszyńskiego}

\author{
Słowa kluczowe \\ konceptualizacja śmierci, neutralizacja, eufemizacja \\ Keywords \\ conceptualisation of death, neutralisation, euphemisation
}

\section{Wprowadzenie}

Jarosław Iwaszkiewicz przez ponad sześć lat (od 1 lutego 1953 r. do 28 maja 1959 r.) związany był (nie tylko uczuciowo) z dużo młodszym od siebie Jerzym Błeszyńskim¹, który stał się m.in. pierwowzorem Janka z opowiadania Kochankowie z Marony, a relacja między sławnym pisarzem a pracownikiem budowlanym z Brwinowa znalazła swoje odbicie także w takich utworach, jak Wzlot czy Wesele pana Balzaka.

Kiedy 27-letni Błeszyński, nieuleczalnie chory na gruźlicę, umiera, Iwaszkiewicz jeszcze przez blisko rok (od 1 czerwca 1959 r. do 3 marca 1960 r.) pisze do niego listy, które

\footnotetext{
${ }^{1}$ Okoliczności spotkania pisarza z „najlepszym tancerzem Brwinowa” - jak go później nazywał - przedstawia Grzegorz Piotrowski w artykule „Nowa miłość Starego. Jarosław Iwaszkiewicz - Jerzy Błeszyński”, w: Mieczysław Dąbrowski, red., Lektury ptci. Polskie (kon)teksty (Warszawa: Elipsa Dom Wydawniczy i Handlowy Włodzimierz Ulicki, 2008), 246.
} 
dopiero niedawno zostały odnalezione i opublikowane w książce pt. Wszystko jak chcesz ${ }^{2}$, gdzie zyskały miano pośmiertnych ${ }^{3}$. Są one świadectwem stanów psychiczno-emocjonalnych pisarza po śmierci młodego brwinowianina oraz uczuć, jakimi twórca ze Stawiska darzył swojego kochanka zarówno przed jego śmiercią, jak i jeszcze długo potem ${ }^{4}$.

Mimo że przedwczesny zgon Błeszyńskiego i wszystkie jego konsekwencje są z oczywistych względów głównym tematem , „listów pośmiertnych”, to dopiero w ostatnim z nich Iwaszkiewicz napisał wprost o tym tragicznym dla obu mężczyzn zdarzeniu, por. wiem teraz, $\dot{z}$ e bardzo cierpiateś, że strasznie nie chciateś umierać ${ }^{5}$ (podpisując ten list - jako jeden z nielicznych - swoim prawdziwym imieniem Jarosław ${ }^{6}$ ), stąd też uwagę czytelnika tej nietypowej korespondencji (a przede wszystkim badacza językowych cech owych tekstów) musi zwrócić sposób „mówienia” jej autora o śmierci adresata listów. To stanowi przedmiot analizy w niniejszym artykule, który sytuuję w zakresie badań wykorzystujących metodologię gramatyki stylistycznej ${ }^{7}$, bowiem opis niniejszy dotyczy sposobu formalnojęzykowej kreacji pewnych zjawisk semantycznych. Znaczenie użytego w tytule artykułu rzeczownika neutralizacja należy wiązać przede wszystkim z książkowo-przenośnym znaczeniem czasownika neutralizować ${ }^{8}$. Zastosowane przeze mnie wyrażenie neutralizacja śmierci oznacza zatem chęć osłabienia (a więc w pewien sposób i pokonania) przez Iwaszkiewicza śmierci jako smutnego i nieodwracalnego faktu (a przynajmniej bezsilności wobec tego faktu i jego wpływu na życie pisarza). Ale trzeba też rozumieć neutralizację śmierci jako próbę zniesienia przez

\footnotetext{
${ }^{2}$ Anna Król, oprac., Wszystko jak chcesz. O miłości Jarosława Iwaszkiewicza i Jerzego Błeszyńskiego (Warszawa: Wilk \& Król Oficyna Wydawnicza, 2017), 445-507. Książka ta wszakże zawiera przede wszystkim listy i telegramy z okresu znajomości Iwaszkiewicza z Błeszyńskim, począwszy od roku 1954 (zob. 62-439 i 511-515), której przebieg (krótko) przedstawia i charakteryzuje Błażej Warkocki w książce Różowy język (Warszawa: Wydawnictwo Krytyki Politycznej, 2013), 159, odsyłając jednocześnie do artykułu G. Piotrowskiego (zob. przypis 1).

${ }^{3}$ Zob. Król, Wszystko jak chcesz, 445: listy pośmiertne 1959-1960 Jarosław Iwaszkiewicz do Jerzego Bteszyńskiego (dlatego w dalszej części artykułu, pisząc o nich, będę stosował cudzysłów: „listy pośmiertne”). Ich zbiór liczy 23 teksty oznaczone numerami 226-248 (zob. Król, Wszystko jak chcesz, 447-507). Uzupełnia je list zamieszczony w Dziennikach pisarza pod datą 6 kwietnia 1960 r., zob. Jarosław Iwaszkiewicz, Dzienniki 1956-1963 (Warszawa: Czytelnik, 2010), 365. Warto nadmienić, że adresat tych listów pojawia się w Dziennikach Iwaszkiewicza po raz pierwszy w zapiskach z 1955 r., kiedy ich autor wspomina o Jurku B. - postaci z pomyślanego, ale nigdy nienapisanego opowiadania, zob. Jarosław Iwaszkiewicz, Dzienniki 1911-1955 (Warszawa: Czytelnik, 2010), 507.

${ }^{4}$ Zob. Andrzej S. Dyszak, „Kochankowie ze Stawiska. Językowy obraz uczuć Jarosława Iwaszkiewicza w jego listach do zmarłego Jurka Błeszyńskiego”, w: Barbara Zwolińska, Krystian Maciej Tomala, red., (Nie) męskość w tekstach kultury XIX-XXI wieku (Gdańsk: Wydawnictwo UG, 2019), 408-421.

${ }^{5}$ Król, Wszystko jak chcesz, 506. Podkreślenia w cytowanych fragmentach listów i dzienników Iwaszkiewicza są moje - A.S.D.

${ }^{6}$ Większość z listów wcześniejszych podpisuje innymi imionami, w kolejności: Roman, Adam (2 razy), Gabriel, Zygmunt, Witold, Stanistaw, Xawery, Krzysztof, Kazimierz, Teofil, Tadeusz, Agapit, Zenon, Karol, Janusz, Arkady i Atanazy. Imieniem Jarostaw podpisane są - poza listem ostatnim - tylko listy oznaczone numerami 234 i 244 (pod listem 237 widnieje podpis Jar, a list o numerze 241 nie ma podpisu).

${ }^{7}$ Zob. Teresa Skubalanka, Wprowadzenie do gramatyki stylistycznej języka polskiego (Lublin: Wydawnictwo Uniwersytetu Marii Curie-Skłodowskiej, 2000), 13-53.

${ }^{8}$ Zob. odpowiednią definicję w USJP: «czynić nieszkodliwym, osłabiać».
} 
Iwaszkiewicza opozycji ${ }^{9}$ między (realną) śmiercią młodego przyjaciela a jego (fikcyjnym) życiem poprzez wykreowanie (za pomocą różnych środków językowych) w tekstach analizowanych listów świata, w którym Błeszyński nadal żyje.

Już w pierwszym zdaniu pierwszego listu, napisanego czwartego dnia po śmierci Błeszyńskiego, Iwaszkiewicz, zwracając się do niego bezpośrednio i nazywając go syneczkiem kochanym i przyjacielem jedynym ${ }^{10}$, pisze o jego (rzekomym) wyjeździe do Surabai, por. czwarty dzień mija, odkąd wyjechateś do Surabai ${ }^{11}$. W kolejnych listach mowa jest też o podróży Błeszyńskiego do tejże Surabai, por. kiedyśmy naprawde jeszcze rozmawiali przed Twoja podróżą do Surabai ${ }^{12}$, i równolegle - o jego tam pobycie, por. A przecież Ty jesteś już w Surabai ${ }^{13}$.

Surabaja to nazwa indonezyjskiego miasta, które było rzeczywistym celem rozważanego przez Błeszyńskiego wyjazdu do pracującego tam jego brata Zbigniewa ${ }^{14}$, by w wyniku podjęcia w Surabai pracy móc i sobie polepszyć warunki życia po powrocie do Polski. Świadectwem planów Błeszyńskiego jest m.in. fragment wiersza jego autorstwa, który Iwaszkiewicz zacytował jako motto wspomnianego wyżej pierwszego z „listów pośmiertnych”:

\section{Za wszelka cenę dziś się starać \\ Uciec od troski bytu tu, Najlepsza będzie Surabaja, \\ Doswidanja, prijatieli, adiu! ${ }^{15}$}

\footnotetext{
${ }^{9}$ Pojęcie „zniesienia opozycji” wyraża termin neutralizacja, jaki stosowany jest w językoznawstwie. Zgodnie z kwalifikacją w USJP leksem neutralizacja funkcjonuje tylko jako termin, także chemiczny, polityczny i sportowy.

${ }^{10} \mathrm{~W}$ żadnym z nagłówków „listów pośmiertnych” nie pojawia się imię Błeszyńskiego, tylko w nagłówku wspomnianego wyżej listu zapisanego w Dziennikach 1956-1963 (zob. przypis 3) Iwaszkiewicz użył formacji zdrobniającej Jureczku. Natomiast kilka razy Iwaszkiewicz stosuje adresatywne formy imienia Błeszyńskiego w treści lub zakończeniu analizowanych listów: jednokrotnie pojawia się zdrobnienie Jureczku (list 230), cztery razy Jerzy (zob. listy 233, 234), w tym raz jest to użycie podwojone: Jerzy, Jerzy (w liście 234), a raz w szeregu ze zdrobniałym wołaczem Jurku (także w liście 234). Jeden raz używa wyrażenia mój Jurek, ujmując je w cudzysłów (zob. list 240), a w ostatnim liście pojawia się wołacz Jurku w cytowanych słowach „starej”, matki Lilki - kochanki Błeszyńskiego.

${ }^{11}$ Król, Wszystko jak chcesz, 447.

12 Tamże, 463/464.

13 Tamże, 478.

${ }^{14}$ Zob. Surabaja, w: Król, Wszystko jak chcesz, 21.

${ }^{15}$ Król, Wszystko jak chcesz, 447 (pisownia wyrazu adiu zgodna z oryginałem). Wiersz ten w całości został utrwalony przez Iwaszkiewicza w Dziennikach pod datą 10 czerwca 1959 r. (Iwaszkiewicz, Dzienniki 1956-1963, 291), wszakże zapis cytowanej zwrotki nieco się różni od jej zapisu w Dziennikach: wersy (poza pierwszym) zaczynają się małymi literami, a wers ostatni ujęty został w cudzysłów (inaczej też w tym wersie zostały zapisane wyrazy pierwszy i trzeci, por. do swidanja i adieu).
} 
Na przeszkodzie planowanej podróży Błeszyńskiego do realnej Surabai stanęła przede wszystkim śmiertelna choroba, na którą cierpiał ${ }^{16}$, ale motyw tego niedoszłego wyjazdu Iwaszkiewicz wykorzystał do zastąpienia nim w całym analizowanym zbiorze listów obrazu śmierci ukochanego, ujmując ją z jednej strony jako moment, kiedy zakończyło się życie Błeszyńskiego (punkt na osi czasu - śmierć ${ }_{1}^{17}$ ), który jest nazywany odjazdem lub wyjazdem ${ }^{18}$, a z drugiej - jako zdarzenie rozciągnięte w czasie (już po zgonie - śmierć ${ }_{2}$ ) i nazwane podróża albo wyjazdem ${ }^{19}$. Zatem pojawiająca się w listach nazwa Surabaja jest symboliczną nazwą miejsca pośmiertnego pobytu bliskiej Iwaszkiewiczowi osoby, gdzie trafiać miały też pisane (ale niewysyłane tam) jego listy, por. wiadomo było, że nie pojedziesz [...], że czeka Ciebie inna, czarna Surabaja, do której pisuję listy ${ }^{20}$ (należy w tym miejscu zwrócić uwagę na istotne - dla takiego rozumienia omawianej nazwy - jej określenia: inna, czyli nie ta Surabaja będąca indonezyjskim miastem, i czarna - przymiotnik, który symbolicznie wiąże tę inna Surabaję ze śmiercią $\left.{ }^{21}\right)$.

Poza konsekwentnym kryptonimowaniem śmierci Błeszyńskiego za pomocą wyrazów, wyrażeń i zwrotów z leksykalnego pola podróży w listach Iwaszkiewicza do zmarłego Błeszyńskiego pojawiają się też językowe wykładniki jej konceptualizacji jako nieobecności bliskiej osoby, a w dwóch listach pisarz ujmuje językowo śmierć kochanka w kategorii snu.

\section{Odjazd zamiast śmierci}

Pisząc o śmierci Błeszyńskiego jako o odjeździe/wyjeździe (śmierć ${ }_{1}$ ), Iwaszkiewicz używa albo odpowiednich form czasownika wyjechać, albo peryfrastycznych zwrotów odjechać do

\footnotetext{
${ }^{16}$ Był też drugi powód niezrealizowania zamierzonego przez Błeszyńskiego wyjazdu, o którym Iwaszkiewicz - w sarkastyczny sposób - wspomina jednym zdaniem będącym zapisem w Dziennikach 1956-1963 z 24 sierpnia 1958 r.: „Jedzie do Surabai, a wyląduje w Bydgoszczy” (w Bydgoszczy bowiem mieszkała Lilka Pietraszek, kochanka Błeszyńskiego, z którą romansował w latach 1958-1959, równolegle spotykając się z Iwaszkiewiczem).

${ }^{17}$ Por. definicję znaczenia rzeczownika śmierć w USJP jako terminu medycznego: 2. «nieodwracalne ustanie wszystkich czynności ustroju oraz procesów przemiany materii we wszystkich jego komórkach; zgon».

${ }^{18}$ Chodzi w tym wypadku o wyjazd w pierwszym z utrwalonych w polszczyźnie znaczeń, w którym jest synonimem rzeczownika odjazd, zob. wyjazd 1. w SJPD: «wyjechanie, wyjeżdżanie skąd, odjazd; opuszczenie danej miejscowości, wyruszenie dokąd jakimś środkiem lokomocji» (we wszystkich wypadkach cytowania definicji znaczeń leksykalnych omawianego słownictwa korzystam ze Stownika języka polskiego pod red. Witolda Doroszewskiego (http://www.sjpd.pwn.pl/haslo/wyjazd/), który chronologicznie odpowiada czasom życia i pisarstwa Iwaszkiewicza z rozpatrywanego okresu).

${ }^{19}$ Zob. w SJPD definicję drugiego z jego znaczeń: 2. «podróż, wycieczka dokąd; przejażdżka» (podkreślenia w cytowanych definicjach słownikowych są moje - A.S.D.).

${ }^{20}$ Król, Wszystko jak chcesz, 467.

${ }^{21}$ Śmierć jako jeden z przedmiotów symboliki koloru czarnego wymienia Władysław Kopaliński w Stowniku symboli (Warszawa: Wiedza Powszechna, 1990), zob. hasło CZARNY.
} 
Surabai i wyjechać do Surabai, które stają się tekstowymi synonimami czasownika umrzeć ('przestać żyć'22), por.

Dzisiaj płaczę cały dzień [...] z tego powodu [...], że wyjechałes s. $^{23}$ (= ...że umarłeś/nie żyjesz);

wówczas kiedy Ty już odjechałeś do słonecznej Surabai ${ }^{24}$ (= ...Ty już umarłeś/nie żyjesz);

czwarty dzień mija, odkąd wyjechateś do Surabai ${ }^{25}$ (= ..odkąd umarłeś/nie żyjesz).

Obok nich, i znacznie częściej, pisarz stosuje różne formy wskazanych już wcześniej rzeczowników odjazd i wyjazd oraz współtworzonych za ich pomocą peryfraz odjazd do Surabai i wyjazd do Surabai, unikając w ten sposób użycia leksemu śmierć (= śmierć ${ }_{1}$ ), por.

byłem przy Tobie do samego Twojego odjazdu ${ }^{26}$ (= ...do samej Twojej śmierci);

Twoje ostatnie stowa przed odjazdem ${ }^{27}$ (= . . przed śmiercią);

co Ci powiedziałem przed Twym odjazdem i po Twoim odjeździ ${ }^{28}$ (= ...przed Twoją śmiercią i po Twojej śmierci);

już po Twoim odjeździe ${ }^{29}$ (= ...po Twojej śmierci);

dzisiaj, po Twoim wyjeździe ${ }^{30}$ (= ...po Twojej śmierci);

te dnie po Twoim wyjeździe ${ }^{31}$ (= ...po Twojej śmierci);

mój smutek, spowodowany Twoim wyjazdem ${ }^{32}$ (= ...Twoją śmiercią);

A po Twoim wyjeździe jestem $\operatorname{sam}^{33}$ (= A po Twojej śmierci...);

Po raz pierwszy od Twojego wyjazdu zaczynam mieć sny o Tobie ${ }^{34}$ (= ...od Twojej śmierci ...);

\footnotetext{
22 Por. definicję pod hasłem umierać - umrzeć w SJPD: «kończyć życie, przestawać żyć; konać».

${ }^{23}$ Król, Wszystko jak chcesz, 495.

24 Tamże, 480.

25 Tamże, 447.

${ }^{26}$ Tamże, 504.

27 Tamże.

28 Tamże, 507.

29 Tamże, 484

30 Tamże, 449.

31 Tamże, 450.

32 Tamże, 458.

33 Tamże, 492.

34 Tamże, 498.
} 
w wigilię odjazdu do świetlistej Surabai ${ }^{35}$ (= w wigilię śmierci);

stałe pożycie z Lilka [...] aż do Twojego wyjazdu do Surabai ${ }^{36}$ (= ...do Twojej śmierci); mijaja 4 tygodnie od Twojego wyjazdu do Surabai ${ }^{37}$ (= ..od Twojej śmierci); dzieliło podróż do Kopenhagi od wyjazdu Twojego do Surabai ${ }^{38}$ (= ...od śmierci Twojej).

Za wyraźny tekstowy (i peryfrastyczny) synonim rzeczownika śmierć (= śmierć $)$ trzeba także uznać związek składniowy rzeczownika odjazd z przymiotnikiem ostateczny, por. Na dwa tygodnie przed Twoim ostatecznym odjazdem mówiłeś jeszcze o wycieczce do Stowacji (= ...przed Twoją śmiercią... $)^{39}$. Z kolei w innym zdaniu na odczytanie tekstowego znaczenia rzeczownika odjazd jako synonimu tego samego rzeczownika śmierć wpływ ma użycie przysłówka nieuchronnie, por. To [twoje] poczucie nieuchronnie zbliżającego się $\boldsymbol{o d j a z d}^{40}$ (= nieuchronnie zbliżającej się śmierci), gdyż bezsprzecznie tylko śmierci nie można uniknąć (musi nastąpić) ${ }^{41}$.

Jednokrotnie wyrażenie odjazd do Surabaji pojawiło się w „listach pośmiertnych" w odniesieniu nie do faktu/momentu śmierci Błeszyńskiego, ale do jego umierania, które w dramatyczny sposób przebiegało przez ponad dziesięć dni w szpitalu „na Turczynku”ł2, por. Ja jej opowiadałem cały Twój odjazd do Surabaji ${ }^{43}$ (= . . całe Twoje umieranie).

W jednym z listów Iwaszkiewicz użył eufemizmu opuścić kogoś, utrwalonego w języku polskim w tym samym znaczeniu, co czasownik umrzećc ${ }^{44}$, por. dziś już trzy tygodnie od

\footnotetext{
35 Tamże, 502.

36 Tamże, 450.

37 Tamże, 471.

38 Tamże, 497.
}

39 Zob. jedną z definicji znaczenia przymiotnika ostateczny w SJPD: 1. «taki, na którym kończy się jakiś cykl, szereg, jakaś seria itp., taki, po którym nie będzie, nie może być innego (z tego rodzaju, z tej serii), niemożliwy do powtórzenia, do zmiany, taki, od którego nie ma odwołania; ostatni, definitywny».

40 Król, Wszystko jak chcesz, 454.

41 Zob. w SJPD definicje znaczeń przysłówka nieuchronnie: książk. «w sposób nieuchronny, nieunikniony; nieodzownie, bezwzględnie, koniecznie» i przymiotnika nieuchronny: książk. «taki, przed którym nie można się uchronić, nieunikniony, nieodzowny, fatalny».

42 Zob. Iwaszkiewicz, Dzienniki 1956-1963, 324-330.

43 Król, Wszystkojak chcesz, 484. Tu zwraca odmienny niż poprzednio zapis formy dopełniacza nazwy Surabaja (por. wyżej Surabai). Iwaszkiewicz - jak widać - stosuje też jej zapis nieortograficzny.

44 Zob. Anna Dąbrowska, Stownik eufemizmów polskich (Warszawa: Wydawnictwo Naukowe PWN, 1998), hasło OPUŚCIĆ kogoś / coś (NAGLE, PRZEDWCZEŚNIE, ZA WCZEŚNIE) - umrzeć. Autorka ta w innej swojej pracy przytacza też eufemistyczny zwrot opuścić grono rodzinne, zob. Eufemizmy współczesnego języka polskiego (Wrocław: Wydawnictwo Uniwersytetu Wrocławskiego, 1994), 95, pochodzący z inskrypcji nagrobnej Przedwcześnie opuścił grono rodzinne, zanotowanej z kolei przez Kazimierza Długosza i zacytowanej w pracy Inskrypcje nagrobne z Pomorza Zachodniego w ujęciu językoznawczym (Szczecin: Wydawnictwo Naukowe Uniwersytetu Szczecińskiego, 1991), 52. 
dnia, kiedy zdecydowateś się nas opuścićt5. Być może używając czasownika opuścić, a nie jednego z czasowników odjechać czy wyjechać (por. dziś już trzy tygodnie od dnia, kiedy zdecydowateś się odjechać/wyjechać) ${ }^{46}$, Iwaszkiewicz chciał wyrazić pretensję do Błeszyńskiego o to, że ten pozostawił pisarza samego, porzucił $\mathrm{go}^{47}$. Znamienne jest też (w tym kontekście) użycie przez autora listu drugoosobowej formy czasownika zdecydować się $e^{48}$ (w odniesieniu do adresata), tak jakby to Błeszyński sam zadecydował o swojej śmierci ${ }^{49}$.

\section{Podróż zamiast śmierci}

Konceptualizacja śmierci (a także umierania) jako podróży ma swój wyraz w języku polskim w eufemizmie ostatnia podróż ${ }^{50}$. Iwaszkiewicz wszakże w odniesieniu do śmierci Błeszyńskiego (śmierć ${ }_{2}$ ) używa albo samego rzeczownika podróż, albo wyrażenia podróż do Surabai, por. np.

jadę bowiem do Sandomierza, aby rozmyślać [...] o Twojej podróży ${ }^{51}$ (= ... Twojej śmierci);

kiedyśmy naprawdę jeszcze rozmawiali przed Twoja podróżą do Surabai ${ }^{52}$ (= ...przed Twoją śmiercią).

W tym samym znaczeniu w ,listach pośmiertnych” pojawia się też synonimiczny do podróży (zarówno w podstawowym, jak i tym tekstowym znaczeniu) rzeczownik wyjazd ${ }^{53}$, który (podobnie jak podróż) pozwala Iwaszkiewiczowi nie mówić wprost o śmierci kochanka, por.

\footnotetext{
${ }^{45}$ Król, Wszystko jak chcesz, 464.

${ }^{46}$ Wszakże czasownik opuścić może być uznany za synonim czasownika wyjechać, por. odpowiednią definicję w SJPD: 3. «odchodzić od kogo, skąd, zostawić kogo samego, oddalać się, wyjeżdżać skąd; występować skąd, porzucać co».

${ }^{47}$ Por. w cytowanej definicji znaczenia czasownika opuścić (przypis poprzedni): 'zostawić kogo samego, porzucać kogo'.

${ }^{48}$ Znaczenie czasownika zdecydować się definiuje się w SJPD (pod hasłem zdecydować) m.in. następująco: 1. «powziąć decyzję, zwłaszcza co do wyboru czego, kogo».

${ }^{49}$ Istotne dla tej interpretacji są fragmenty Dzienników Iwaszkiewicza, w których pisarz wspomina, że Jurek w ostatni poniedziałek przed śmiercią „zamówił” sobie na czwartek (na swój pogrzeb) księdza, który go wówczas spowiadał w szpitalu na Turczynku (zob. Iwaszkiewicz, Dzienniki 1956-1963, 328), a w rzeczony czwartek (święto Bożego Ciała) każe obecnym przy nim bliskim wysłać telegramy: „Do wszystkich, wyślijcie telegramy do wszystkich: Jurek umarł!” (Iwaszkiewicz, Dzienniki 1956-1963, 330). Umiera tego samego dnia o godz. 21.30.

${ }^{50}$ Zob. Dąbrowska, Stownik eufemizmów, hasło OSTATNIA PODRÓŻ - śmierć, umieranie.

${ }^{51}$ Król, Wszystko jak chcesz, 449.

52 Tamże, 463/464.

${ }^{53}$ Zob. wyżej-przypis 19.
} 
Do ostatniej chwili przed wyjazdem [por. przed podróżą] tak pisateś - i chyba się już z tego nie poprawisz ${ }^{54}$ (= ...przed śmiercią...);

moje uczucia do Twojego wyjazdu [por. do Twojej podróży] przeszły dość dziwna ewo$\operatorname{lucję}^{55}$ (= ...do Twojej śmierci...).

Istotną cechą podróży jest przemieszczanie się w przestrzeni i w czasie (od punktu początkowego do punktu końcowego). Początek podróży Błeszyńskiego wyznaczają wskazane wcześniej inchoatywny czasownik odjechać i utworzony od niego rzeczownik odjazd, a punktem startowym podróży jest cmentarna kaplica, por. Tłumaczyłem $\mathrm{Ci} w$ tej ostatniej rozmowie, w kapliczce na Turczynku ${ }^{56}$. Pojawia się też motyw pożegnania z osobą wyruszającą w podróż, jednakże Iwaszkiewicz żegna się z Błeszyńskim, który nie tylko spakował się (spakował swoje rzeczy) przed podróżą ${ }^{57}$, ale i sam został na tę podróż spakowany (włożony, tu: do trumny, jak rzecz), por. Pamiętam w naszej ostatniej rozmowie, kiedy byteś już zupetnie spakowany do wyjazdu i nawet samego Ciebie ułożono do takiej drewnianej skrzynki ${ }^{58}$. Ważne jest tu użycie czasownika ułożyć, który wskazuje na leżącą pozycję osoby przygotowanej do podróży ${ }^{59}$. W obu cytowanych fragmentach należy też zwrócić uwagę na wyrażenie ostatnia rozmowa, w którym przymiotnik ostatni wskazuje na czas przed śmiercią ${ }^{60}$. Podobnie w innych jeszcze związkach (ostatnie miesiace, ostatnie dni), jakich użył Iwaszkiewicz w „listach pośmiertnych”61, por.

ja wiedziałem, że to sa ostatnie miesiace Twojego życia ${ }^{62}$;

jak często mówiłeś i pisałeś w ostatnich dniach ${ }^{63}$.

\footnotetext{
${ }^{54}$ Król, Wszystko jak chcesz, 453.

55 Tamże, 490.

56 Tamże, 448.

${ }^{57}$ Por. definicję znaczenia czasownika spakować się w SJPD (pod hasłem spakować): «spakować, zapakować swoje rzeczy (w celu zabrania ich w podróż)».

${ }^{58}$ Król, Wszystko jak chcesz, 447/448. Znaczenie przymiotnika spakowany, z racji tego, że jest on prymarnie imiesłowem, nie różni się od podstawowego czasownika spakować, definiowanego w SJPD następująco: «złożyć co w paczkę, umieścić w walizce, kufrze itp. w celu wysłania, zabrania w podróż; napełnić co (walizkę, kufer, skrzynię itp.) rzeczami».

59 Por. odpowiednią definicję pod hasłem układać-ułożyć w SJPD: 3. «zmieniać pozycję pionową czego lub kogo na poziomą; kłaść, umieszczać kogo, co gdzie w pozycji leżącej, poziomej».

${ }^{60}$ Zob. następującą definicję pod hasłem ostatni w SJPD: 1. «znajdujący się na końcu, kończący jakiś cyk1, szereg, jakąś serię itp.; taki, który pozostał sam, po którym nie będzie innego».

${ }^{61} \mathrm{Tu}$ też wskazać trzeba wspomniany wyżej eufemizm ostatnia podróż.

${ }^{62}$ Król, Wszystko jak chcesz, 476.

${ }^{63}$ Tamże, 492.
} 
Z kolei drewniana skrzynka (eufemizm rzeczownika trumna ${ }^{64}$ ) wywołuje oczywiste skojarzenie z Trenami Jana z Czarnolasu, w których Urszulka została także w jednej skrzynce zamkniona $^{65}$. W innym z listów Iwaszkiewicz nazwał tę skrzynkę Błeszyńskiego kuferkiem, por. całowałem Twoje włosy w tym Twoim kuferku ${ }^{66}$, co jest kolejnym wyrazem ujmowania śmierci kochanka jako podróży, choć całowanie we włosy przypomina nie pożegnanie przed podróżą, ale raczej rytuał przedpogrzebowy ${ }^{67}$.

Podróż Błeszyńskiego do „,innej” Surabai okazuje się podróżą morską, oceaniczną ${ }^{68}$, tak jakby odbywała się do tej prawdziwej Surabai - portowego miasta na wyspie Jawie położonej między Pacyfikiem a Oceanem Indyjskim, na co wskazują użyte przez Iwaszkiewicza takie rzeczowniki, jak morze, ocean, fala, port, tódź, por.

jaki będzie Twój najbliższy port ${ }^{69}$;

nie wiem, jakie morze Cię kolysze: Śródziemne, Czerwone? ${ }^{70}$;

kiedy Ty unosisz się na niebiesko-złotych falach, zmierzajac do słonecznej krainy pogody i szczéśliwości $i^{71}$;

bo już między nami stała czarna i okropna tódź, która Cię zabrała w podróż na świetliste oceany ${ }^{72}$.

Nie bez znaczenia są tu także czasowniki kołysać się i unosić się, wskazujące na specyficzny sposób przebiegu podróży Błeszyńskiego, której jest on pasywnym uczestnikiem (woda go unosi $^{73}$, co wynika ze stanu, w jakim się znajduje - jest martwy. Natomiast spośród rzeczowników wskazanych w cytowanych fragmentach listów należy przede wszystkim zwrócić uwagę na rzeczownik łódź i określające go przymiotniki czarna ${ }^{74}$ i okropna, które

\footnotetext{
64 Zob. Dąbrowska, Stownik eufemizmów: hasła SKRZYNKA i DREWNIANA SKRZYNIA - trumna.

65 Tren VII, w: Jan Kochanowski, Treny (Warszawa: Państwowy Instytut Wydawniczy, 1975), 15.

66 Król, Wszystko jak chcesz, 480.

67 O całowaniu zmarłych na pożegnanie pisze Kopaliński (choć nie wspomina o całowaniu włosów), zob. Słownik symboli, hasło POCAŁUNEK.

68 Wybór oceanu jako szlaku podróży Błeszyńskiego być może jest nieprzypadkowy, bowiem ocean był w starożytności symbolem śmierci, zob. Kopaliński, Słownik symboli, hasło MORZE.

69 Król, Wszystko jak chcesz, 447.

70 Tamże, 455.

71 Tamże, 457.

72 Tamże, 464.

73 Zob. definicje znaczeń obu czasowników w SJPD: kołysać «wprawiać w ruch jednostajny, monotonny; wykonywać jednostajne, monotonne ruchy; poruszać jednostajnie, monotonnie; huśtać, bujać, wahać», unosić się (pod hasłem unosić): 2. «utrzymywać się na pewnej wysokości nad ziemią, na powierzchni czego, w czym».

74 Należy w tym miejscu przypomnieć, że przymiotnika czarna Iwaszkiewicz użył także jako określenia rzeczownika Surabaia - nazwy miejsca pośmiertnego pobytu Błeszyńskiego (zob. wyżej - Wprowadzenie).
} 
pozwalają na dwie interpretacje jego znaczenia. Iwaszkiewicz mógł łodzia nazwać trumnę $e^{75}$ $\mathrm{z}$ ciałem kochanka (łódź bowiem, która zabrała Błeszyńskiego w jego ostatnią podróż, jest czarna i okropna i to tę łódź-trumnę unosza fale i kołysze morze), ale mógł też w ten sposób nawiązać do mitologicznej łodzi Charona przewożącego dusze zmarłych przez rzeki Hade$\mathrm{su}^{76}$. Ta interpretacja znajduje potwierdzenie w liście, w którym pojawia się nieśmiała nadzieja Iwaszkiewicza na powrót Błeszyńskiego, por. może w Surabai nie uznają Polskiej waluty i nie przyjma Ciebie [...] Ale chyba nie wrócisz? Boże, co by to była za radość!77 (jak można sądzić, wyrażeniem Polska waluta Iwaszkiewicz nawiązuje do opłaty w postaci jednego obola, jaką Charon pobierał od zmarłych za przewóz jego łodzią $\left.{ }^{78}\right)$.

Nie da się jednakże nie zauważyć kontrastu między czarną i okropną łodzia (trumną) a świetlistymi oceanami o niebiesko-złotych falach (które ją niosą) czy słoneczna kraina pogody i szczęśliwości (dokąd trafia), jaką okazuje się być Surabaja (pierwotnie scharakteryzowana wszakże za pomocą określenia czarna, zob. wyżej - Wprowadzenie): słoneczna, a więc 'jasna $=$ pełna światła'79, nie czarna $=$ 'pozbawiona światła'80. Przymiotnik słoneczna pojawi się w następnych „listach pośmiertnych” jeszcze kilkakrotnie:

Tak się odmieniasz, odchodzisz, oddalasz - w stonecznej Surabai nie ma miejsca na moją miłość... ${ }^{81}$;

kiedy Ty już odjechałeś do stonecznej Surabai ${ }^{82}$;

Szkoda, że mnie nie zastrzeliłeś. Leżelibyśmy teraz koło siebie - w gondoli, która płynie do stonecznej Surabai ${ }^{83}$;

Zwyczajnie zapomniałeś o mnie w tej stonecznej krainie s4. $^{84}$

\footnotetext{
75 Zob. w SJPD definicję znaczenia przymiotnika okropny: 1. «budzący grozę; straszny, straszliwy, rozpaczliwy, beznadziejny». Spośród dwóch artefaktów: łodzi i trumny to określenie bardziej przynależy trumnie.

${ }^{76}$ Zob. Władysław Kopaliński, Słownik mitów i tradycji kultury (Warszawa: Państwowy Instytut Wydawniczy, 1985), hasło CHARON.

77 Król, Wszystko jak chcesz, 477.

${ }^{78}$ Władysław Kopaliński twierdzi, że ta tradycyjna interpretacja obola jest błędna, bowiem obol umieszczony w ustach albo dłoni zmarłego był ofiarowaną mu namiastką podzielonego po śmierci jego majątku, por. Kopaliński, Stownik symboli, hasło CHARON, podhasło Opłata Charona.

${ }^{79}$ Por. następującą definicję znaczenia przymiotnika słoneczny w SJPD: 2. «wystawiony na światło słońca; wypełniony światlem słońca; nie zacieniony, nasłoneczniony».

${ }^{80}$ Por. jedną z definicji przymiotnika czarny w SJPD: 3. «mroczny, nie oświetlony».

${ }^{81}$ Król, Wszystko jak chcesz, 472.

82 Tamże, 480.

${ }^{83}$ Tamże, 498. W zdaniu tym, wyrażającym marzenie Iwaszkiewicza o wspólnej z Błeszyńskim podróży do Surabai, łódź-trumna zostaje zmieniona w gondolę (rzeczownik gondola - jak się wydaje - wywołuje asocjacje kochanków, którzy wybierają gondolę dla romantycznej przejażdżki po kanałach Wenecji).

84 Tamże, 505.
} 
Miejsce pośmiertnego pobytu Błeszyńskiego nie jest więc mrocznym Hadesem, do którego wiozła umarłych łódź Charona, lecz przypomina teologiczną wizję raju (nieba) ${ }^{85}$, por.

jest Ci dobrze i nie pamiętasz o naszych ziemskich troskach ${ }^{86}$;

Napisałem to wszystko dla kawatu, bo przecie w Surabai to wszystko Ci niepotrzebne ${ }^{87}$;

Ty jesteś już w Surabai, szczęśliwy, promienny ${ }^{88}$.

W taki właśnie obraz Surabai wpisuje się też wspomniana przez Iwaszkiewicza w jednym z „listów pośmiertnych” wypowiedź jego żony: Hania twierdzi, że jesteś tam świetlistym aniołem $^{89}$ (użyty przez autorkę tego sądu przymiotnik świetlisty, którym wcześniej Iwaszkiewicz określił oceany unoszące zmarłego Błeszyńskiego, współgra z przymiotnikiem stoneczny jako określeniem Surabai - łączy je semantycznie światło ${ }^{90}$ ).

W kilku listach pojawiają się informacje o czasie trwania podróży, por.

czwarty dzień mija, odkąd wyjechałeś do Surabai ${ }^{91}$;

dziś już trzy tygodnie od dnia, kiedy zdecydowałeś się nas opuścicic2;

mijają 4 tygodnie od Twojego wyjazdu do Surabai ${ }^{93}$,

aż w jednym z kolejnych listów Iwaszkiewicz konstatuje: dostaliśmy niespodziewanq wiadomość, że dojechateś już do Surabai ${ }^{94}$ (partykuła już w połączeniu z czasownikiem dojechać wzmacnia komunikat o zakończeniu przebytej drogi).

Pisząc o przybyciu Błeszyńskiego do miejsca, które ma być kresem podróży, wskazanego wyrażeniem do Surabai, Iwaszkiewicz użył nie tylko terminatywnego czasownika dojechać (jak w cytowanym wyżej zdaniu), ale również rzeczownika przybycie, por. nie dałeś mi znać ani słowem, ani gestem o Twoim przybyciu do Surabai ${ }^{95}$.

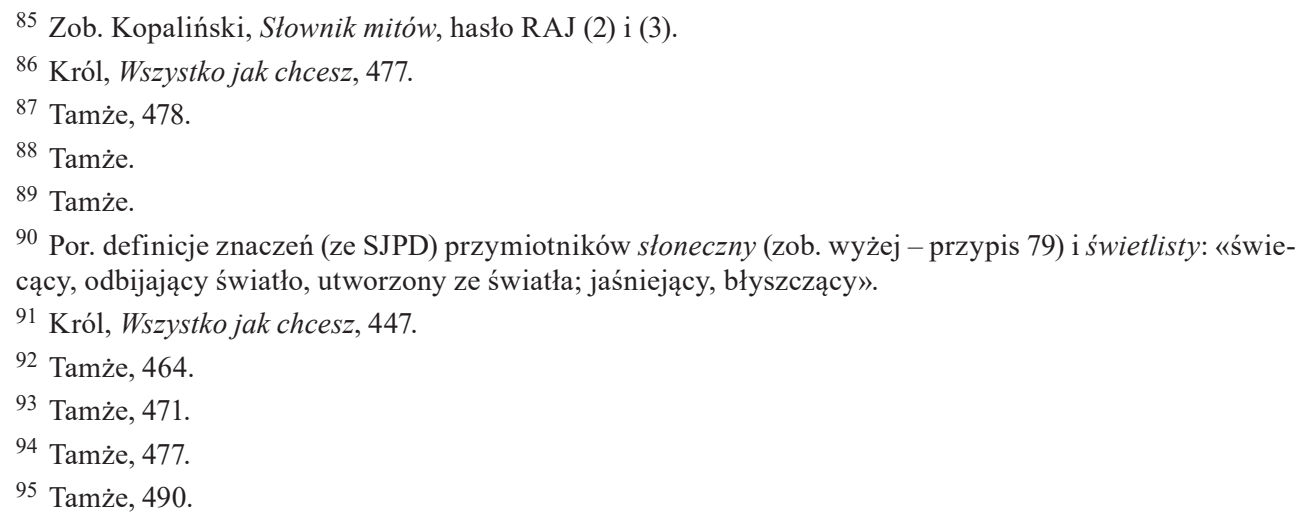


Osiągnięcie celu podróży wyrażają też: powtórzony dwukrotnie przez Iwaszkiewicza zwrot współtworzony przez czasownik być i wielokrotnie używane w „listach pośmiertnych" wyrażenie $w$ Surabai, por.

\section{A przecież Ty jesteś już w Surabai ${ }^{96}$;}

Ale Ty jesteś w Surabai ${ }^{97}$

oraz czasownik byc ${ }^{98} \mathrm{z}$ szeregiem rzeczowników charakteryzujących to miejsce: stońce, zapach, zieleń, por. Więc już jesteś $w$ tym słońcu, zapachu, zieleni ${ }^{99}$ (dodatkowym wykładnikiem trwania jest partykuła już, za pomocą której Iwaszkiewicz podkreśla, że pobyt Błeszyńskiego w Surabai trwa od pewnego czasu).

\section{Nieobecność i oddalenie zamiast śmierci}

Bezpośrednim sposobem mówienia przez Iwaszkiewicza o śmierci Błeszyńskiego jako o jego nieobecności są użycia przymiotnika nieobecny ${ }^{100}$, rzeczownika nieobecność ${ }^{101}$ i zaprzeczonej formy czasownika być (nie $m a)^{102}$, por.

synusiu drogi - i nieobecny ${ }^{103}$;

przerażająca jest myśl o Tobie i Twojej nieobecności ${ }^{104}$;

Dzisiaj płaczę cały dzień [...] z tego powodu, że Cię nie ma ${ }^{105}$.

\footnotetext{
96 Tamże, 478.

97 Tamże, 506.

${ }^{98}$ Chodzi o być w funkcji samodzielnej o znaczeniu zdefiniowanym w SJPD następująco: 3. «być obecnym, przebywać, stać, tkwić». Lepiej to znaczenie oddaje odpowiednia definicja w USJP, por. 2. «być
} obecnym, przebywać, znajdować się gdzieś».

${ }^{99}$ Król, Wszystko jak chcesz, 477.

100 Zob. definicję jego znaczenia w SJPD: «o ludziach: nie znajdujący się w danym miejscu».

${ }^{101}$ Zob. definicję jego znaczenia w SJPD: «nieznajdowanie się w jakimś miejscu, brak kogo w jakim miejscu».

102 Jeśli jedno ze znaczeń czasownika być w funkcji samodzielnej definiuje się w SJPD w następujący sposób: 3. «być obecnym, przebywać, stać, tkwić», to znaczenie jego zaprzeczonego odpowiednika można zdefiniować tak: «być nieobecnym, nie przebywać».

${ }^{103}$ Król, Wszystko jak chcesz, 492.

104 Tamże, 492/493.

105 Tamże, 495. 
Pośrednio brak Błeszyńskiego wyrażają też takie konstatacje Iwaszkiewicza, jak Trzy tygodnie bez Ciebie! ${ }^{106}$ ( bez twojej obecności/nie ma ciebie) oraz i jeszcze jutro nie będę Cię widzial $^{107}$ ( nie będziesz obecny/nie będzie cię tutaj).

Za pomocą innych środków językowych Iwaszkiewicz wyraża też oddalenie Błeszyńskiego, a w konsekwencji - niemożność spotkania się z kochankiem. Są to zarówno środki leksykalne (systemowe), por. Ty mi na to wszystko odpowiesz, [...] odpowiesz z dalekiej Surabai ${ }^{108}$ i bardzo mi jest trudno tłumaczyć Ci wiele rzeczy na taka odlegtość ${ }^{109}$, kochanku mój nieosiągalny! ${ }^{110}$, jak i składniowe (tekstowe), por. Ty jesteś tak daleko i taki nieosiagal$n y^{111}$. Towarzyszące im określenia ilościowe: taka (odległość), tak (daleko), taki (nieosiągalny) są wykładnikami wysokiego stopnia nasilenia cech wyrażonych ich składniowymi nadrzędnikami ${ }^{112}$. Funkcję wskazującą na oddalenie pełni też przedrostek od- w omówionym wyżej (zob. wyżej - Wprowadzenie) czasowniku odjechać (obok pełnienia w nim funkcji wskazywania na początek podróży) ${ }^{113}$.

W ostatnim liście pisanym do nieżyjącego kochanka Iwaszkiewicz wyraża pragnienie: dałbym wszystko za to, abyś w tej chwili kłamat przede mna od rana do wieczora, ale żebyś byt koło mnie, abym słyszał Twój głos, dotykat Twoich włosów, widział Twoje oczy ${ }^{114}$, a ponad cztery lata po śmierci Błeszyńskiego, 25 września 1963 roku, Iwaszkiewicz zanotował w swoich Dziennikach: I nikogo obok mnie. Jurek B[łeszyński] jaki byt, taki byt, ale póki żyt, byt przy mnie. Wszystko jedno, co nim powodowato, ale by $\boldsymbol{t}^{115}$.

\footnotetext{
106 Tamże, 469.

107 Tamże, 456.

108 Tamże, 489. Por. definicję znaczenia przymiotnika daleki (jako określenia rzeczownika Surabaja) w SJPD: 1. «znajdujący się, położony w dużej odległości; odległy, oddalony».

${ }^{109}$ Król, Wszystko jak chcesz, 453. Por. definicję rzeczownika odległość w SJPD: 1. «przestrzeń oddzielająca od siebie dwa porównywane pod tym względem punkty; dystans, odstęp».

${ }^{110} \mathrm{Król}$, Wszystko jak chcesz, 499. Sens użytego tu przymiotnika nieosiagalny lepiej oddaje bardziej współczesna definicja jego znaczenia w USJP: książk. b) «taki, do którego nie można dotrzeć, z którym nie sposób się spotkać, skontaktować».

${ }^{111}$ Król, Wszystko jak chcesz, 492. Por. w SJPD definicję znaczenia przysłówka współtworzącego orzeczenie analityczne być daleko: 1. a) «w znacznej odległości, w odległym miejscu, w oddaleniu».

112 Zob. odpowiednie definicje w USJP: taki 2. «używany przy rzeczowniku lub przymiotniku, wyraża wysoki stopień intensywności danej cechy», II tak 1. «wyraża wysoki stopień nasilenia cechy lub stanu rzeczy i komunikuje, że jest on większy, niż mówiący tego oczekiwał».

${ }^{113}$ Wymienia się go pod następującą definicją przedrostka od- w SJPD: 1. «przedrostek tworzący czasowniki pochodne (a także inne wyrazy z nimi związane), z uwydatnieniem następujących ważniejszych odcieni, uzupełniających znaczenie czasownika podstawowego»; b) «oddzielenie, oddalenie, wyodrębnienie czego».

${ }^{114}$ Król, Wszystko jak chcesz, 506.

115 Iwaszkiewicz, Dzienniki 1956-1963, 591.
} 


\section{Sen zamiast śmierci}

We wspomnianym na wstępie niniejszego artykułu jedynym liście z II tomu Dzienników, który uzupełnia „listy pośmiertne”, Iwaszkiewicz zwraca się do jego adresata, używając powtórzonej formy drugiej osoby trybu rozkazującego czasownika spać, por. śpij spokojnie, śpij, kochany, ja jestem przy Tobie ${ }^{116}$. Przenośne znaczenie wskazanego czasownika (odnoszące się do śmierci) potwierdza SJPD, por. spać przen. b) «być martwym, pogrzebanym», wszakże nie można go wprost przypisać formie śpij ( $\neq$ 'bądź martwy, pogrzebany'), ale już jego związek z przysłówkiem spokojnie (śpij spokojnie) przypomina zwrot z języka religijnego spoczywaj $w$ pokoju $u^{117}$. W ten sposób zacytowane zdanie wywołuje kolejne skojarzenie z Trenami Jana Kochanowskiego, w których poeta przedstawił śmierć swojej córki Urszulki słowami: Ująt ja sen żelazny, twardy, nieprzespany ${ }^{118}$. Jako znamienne w tym kontekście jawi się również pożegnanie pisarza z Błeszyńskim przygotowanym do pogrzebu w kaplicy „na Turczynku”, o którym Iwaszkiewicz napisał w tym samym tomie Dzienników, por. Dobranoc, dobranoc - jak ci mówiłem do trumny ${ }^{119}$, a przypomniał w jednym z „listów pośmiertnych”, por. Dobranoc, dobranoc ${ }^{120}$. Być może podobne dobranoc - nie jako życzenie „dobrej nocy” - ale jako pożegnanie na sen wieczny (dobranoc = spoczywaj w spokoju) zostało użyte w zakończeniu „listu pośmiertnego” z 23 czerwca 1959 roku, por. Do widzenia, dobranoc ${ }^{121}$ (istotne dla takiej interpretacji wydaje się zestawienie w jednym szeregu formuł grzecznościowych stosowanych w różnych porach dnia).

U Iwaszkiewicza (podobnie zresztą jak i u Kochanowskiego) mówienie o śmierci jako o śnie ma niewątpliwie źródło/uzasadnienie w jego zainteresowaniach kulturą śródziemnomorską, wywodzącą się ze starożytnej Grecji. W mitologii greckiej uosobienia obu stanów, Thanatos - śmierć i Hypnos - sen, są bliźniaczymi braćmi ${ }^{122}$. Podobieństwo śmierci i snu wynika z podobieństwa takich zewnętrznych cech zmarłego i śpiącego, jak ułożenie czy bezwładność ciała i zamknięcie oczu, a także z cech związanych ze świadomością: u śpiącego jest ona ograniczona, z kolei zmarły jest jej pozbawiony.

\footnotetext{
116 Tamże, 365.

117 Zob. Dąbrowska, Eufemizmy, 97. Odnotowany tam zwrot ten pochodzi z inskrypcji nagrobnej Spoczywaj w pokoju, Moniko mała, boś się w życiu wycierpiała, którą pierwotnie zacytował Kazimierz Długosz we wspomnianej wyżej pracy Inskrypcje nagrobne (zob. przypis 44). A. Dąbrowska przytacza też ten sam przykład użycia omawianego zwrotu w Stowniku eufemizmów pod hasłem SPOCZĄĆ / SPOCZYWAĆ W JEZUSIE / W (WIECZYSTYM) (S)POKOJU.

118 Tren VII, w: Kochanowski, Treny, 15. Zob. też Kopaliński, Stownik symboli, hasło ŚMIERĆ, gdzie „Śmierć - wieczny sen".

119 Iwaszkiewicz, Dzienniki 1956-1963, 387.

120 Tamże, 334.

${ }^{121}$ Król, Wszystko jak chcesz, 472.

122 Zob. Dąbrowska, Stownik eufemizmów, hasła SEN i BRAT SNU, Kopaliński, Słownik mitów, hasła TANATOS i HYPNOS, oraz Stownik symboli, hasło ŚMIERĆ (tam śmierć - siostra snu, zapewne ze względu na formę gramatyczną polskiego rzeczownika śmierć).
} 
W mówieniu o śmierci Błeszyńskiego jako o śnie może się także wyrażać wynikająca z tradycji chrześcijańskiej wiara, że śmierć jest stanem przejścia do nowego życia, że nastąpi przebudzenie z niej jak ze snu ${ }^{123}$, a związku z tym - i nadzieja Iwaszkiewicza, iż śmierć Błeszyńskiego jest tylko czasowym z nim rozstaniem. Wiarę tę pisarz wyraził w ostatnim zdaniu ostatniego z „listów pośmiertnych”, wykorzystując motyw podróży do Surabai, por. Będę wkrótce z tobą. I ja pojadę do Surabai ${ }^{124}$.

\section{Zakończenie}

Śmierć Jerzego Błeszyńskiego stała się swoistego rodzaju cezurą w życiu Jarosława Iwaszkiewicza, o czym wprost on sam napisał w swoich Dziennikach pod datą 6 marca 1960 roku, por. A teraz miną rok, zupetnie jakby fala mnie odsunęta od życia, od wszystkiego. I już teraz będa tylko takie odsuwajace fale. Zupetna czarna rozpacz w sercu, rozpacz wegetacji $i$ samotności ${ }^{125}$.

Półtora roku później (3 listopada 1961 r.) w tychże samych Dziennikach pisarz wyraził bezpośrednio swoje niepogodzenie ze śmiercią kochanka, por. Tak bardzo pogodzitem się $z$ tym, że to był okropny człowiek - tak bardzo jestem niepogodzony z jego śmiercią ${ }^{126}$.

Nie mogąc zmienić zaistniałego stanu rzeczy w realnym świecie, Iwaszkiewicz za pomocą odpowiednich środków językowych kreuje w listach pisanych do Błeszyńskiego świat, w którym ich adresat żyje, dlatego zwraca się do niego za pomocą form czasu teraźniejszego $\mathrm{i}$ - jeszcze bardziej wyrazistego - czasu przyszłego, por.

Bo wiesz, Lilka mi wczoraj powiedziała... ${ }^{127}$;

jesteś do mnie przywiazany ${ }^{128}$;

i chyba się już z tego nie poprawisz ${ }^{129}$;

niepokoję się o Ciebie - i jednocześnie irytujesz mnie i drażnisz ${ }^{130}$;

Myślatem o Tobie, o tym, co robisz, kogo widzisz, do kogo się śmiejesz ${ }^{131}$;

123 O chrześcijańskie wizji życia wiecznego w kontekście eufemizmu sen w znaczeniu 'śmierć' pisze

A. Dąbrowska, zob. Eufemizmy, 322.

${ }^{124}$ Król, Wszystko jak chcesz, 507.

125 Iwaszkiewicz, Dzienniki 1956-1963, 359.

126 Tamże, 484.

127 Król, Wszystko jak chcesz, 448.

128 Tamże, 449.

129 Tamże, 453.

130 Tamże, 456.

131 Tamże. 
Przecież wiesz, czym dla mnie jesteś ${ }^{132}$;

Ale, ale, będziesz się strasznie śmiat ${ }^{133}$;

Ty jeden to wszystko zrozumiesz jak ja $a^{134}$,

Widzisz więc, że tylko Ty z moich bliskich możesz zrozumieć to wszystko, co się ze mna dzieje $e^{135}$;

Jak wiesz przepisuje Twoje listy ${ }^{136}$;

Wstydź się, kochany. Myślę, że już się tego wstydzisz-pocaluj mnie, kochany, i nawet nie mów: przepraszam ${ }^{137}$;

skonstatowałem wczoraj, że i tak dużo rzeczy nie mówisz ${ }^{138}$.

Formy te służą podtrzymywaniu kontaktu Iwaszkiewicza z Błeszyńskim. Tę samą funkcję $\mathrm{w}$ analizowanej korespondencji pełnią pytania, które autor listów zadaje ich adresatowi, por.

Czy piękna pogoda tam, gdzie teraz jesteś? ${ }^{139}$;

Czy byłeś dziś u Frontów, czy gdzie indziej? ${ }^{140}$;

... a teraz jak Cię tam karmia $w$ tej Surabaji? ${ }^{141}$;

Czy obejrzałeś mapy Słowacji? ${ }^{142}$;

Czy czytałeś te bzdury w Expressie i fotografie ze „Stawisk”143.

\footnotetext{
132 Tamże, 465. pisarzowi).

134 Tamże, 488.

135 Tamże, 489.

136 Tamże, 493.

137 Tamże, 496.

138 Tamże, 499.

139 Tamże, 452.

140 Tamże, 456.

141 Tamże, 492.

142 Tamże, 457.

143 Tamże.
}

133 Tamże, 478. Pretekstem do przewidywanej wesołości Błeszyńskiego ma być treść korespondencji, jaką niedawno Iwaszkiewicz prowadził z bydgoską malarką Joanną Jonscherową, która „zimny i smutny wzrok" Błeszyńskiego (patrzył w ten sposób na nią, kiedy tańczyli razem w czasie jednego z pobytów z Iwaszkiewiczem w tym mieście) błędnie zrozumiała jako wyraz przygnębienia chorobą (w rzeczywistości wyrażał on niezadowolenie z faktu, że „ta baba nawet chodzić w takt nie umie”, jak potem wyznał 
Funkcji podtrzymywania kontaktu ze zmarłym służą też takie formuły kończące niektóre listy, jak A tymczasem do widzenia ${ }^{144}$ czy trzykrotnie powtórzone Do widzenia, kochany $^{145}$. Wszakże w zakończeniach innych listów pisarz wyraża swoją świadomość faktu, że Błeszyński jest jednak martwy, por.

catuje Twoje zimne usta, Twoje ręce chtodne jak sople lodu-jak wtedy, jak w ten niezapomniany ,ciężki, ogromny” dzień czuwania ${ }^{146}$;

Catuję Twoje zimne recce ${ }^{147}$;

Całuje Twoje usta, o ile jeszcze istnieja $a^{148}$.

Unikając bezpośredniego mówienia o śmierci Błeszyńskiego, autor „listów pośmiertnych" używa niewiele systemowych eufemizmów. Posługuje się przede wszystkim neosemantyzmami (jak odjazd, wyjazd, podróż), wykorzystując je także w peryfrazach (jak odjazd/wyjazd/podróż do Surabai), które nabierają cech frazeologizmów, choć tylko w wymiarze idiolektu pisarza - zakres ich użycia ogranicza się bowiem do analizowanych tekstów Iwaszkiewicza. Co ciekawe, podobnie zbudowanych zwrotów używa on, mówiąc i o swojej śmierci, por.

Listów nie wysyłaj, chowaj je, przeczytamy je razem, gdy przyjadę do Surabai ${ }^{149}$;

Serce mi dziś nawala - może i ja wyniosę się do Surabai ${ }^{150}$.

Zwrot wynieść się do Surabai można uznać za modyfikację eufemistycznej metafory wynieść się na tamten świat ${ }^{151}$, co potwierdza przyjęte na wstępie odniesienie nazwy Surabaja do miejsca pośmiertnego pobytu Błeszyńskiego (Surabaja = tamten świat ${ }^{152}$ ). Jednakże swoją podróż do Surabai Iwaszkiewicz zrealizował dopiero 20 lat później.

Mimo językowej kreacji przez Iwaszkiewicza w analizowanych listach zmarłego kochanka jako osoby nadal żyjącej pojawiają się w tej fikcyjnej rzeczywistości językowe tropy śmierci Błeszyńskiego. Obok wskazanych wyżej zestawień zimne usta, zimne/chłodne ręce pojawiają się jeszcze inne wyrażenia, jak po Tobie, por. W papierach po Tobie znalazłem

\footnotetext{
144 Tamże, 452.

145 Tamże, 457, 480 i 496 (tam bez przecinka: Do widzenia kochany).

146 Tamże, 490.

147 Tamże, 494.

148 Tamże, 502.

149 Tamże, 455.

150 Tamże, 494.

151 Wśród innych metaforycznych eufemizmów wymienią ją A. Dąbrowska, zob. Eufemizmy, 319.

152 Zob. w SJPD świat 1. fraz. Tamten świat, lepszy świat «według wierzeń religijnych: miejsce przebywania człowieka po śmierci; niebo, piekło; zaświaty».
} 
zaczęty i nieskończony Twój wiersz ${ }^{153}$, czy sformułowania nawiązujące do realnych zdarzeń po zgonie przyjaciela, por. zamknątem Ci powieki na Twój wielki odjazd ${ }^{154}$ i dzień czuwania nad Twoim odjazdem ${ }^{155}$. Świadomość śmierci bliskiej pisarzowi osoby przeplata się z niewiarą w ten tragiczny fakt, por. byłem dzisiaj znowu w tym miejscu, gdzie śmieszni ludzie powiadaja, że Ciebie zakopali ${ }^{156}$. Dobitnie wszakże brzmi forma czasu przeszłego czasownika być w jednym ze zdań z ostatniego „listu pośmiertnego”: Wiem tylko, że byteś, że kocham Cię do dziś dnia ${ }^{157}$.

\section{Bibliografia}

\section{Źródło}

Król, Anna, oprac. Wszystko jak chcesz. O miłości Jarosława Iwaszkiewicza i Jerzego Błeszyńskiego, Warszawa: Wilk \& Król Oficyna Wydawnicza, 2017.

Dąbrowska, Anna. Eufemizmy współczesnego języka polskiego. Wrocław: Wydawnictwo Uniwersytetu Wrocławskiego, 1994.

Dąbrowska, Anna. Stownik eufemizmów polskich, czyli w rzeczy mocno, w sposobie łagodnie. Warszawa: Wydawnictwo Naukowe PWN, 1998.

Długosz, Kazimierz. Inskrypcje nagrobne z Pomorza Zachodniego w ujęciu językoznawczym. Szczecin: Wydawnictwo Naukowe Uniwersytetu Szczecińskiego, 1991.

Doroszewski, Witold, red. Stownik języka polskiego. T. I-XI. http://www.sjpd.pwn.pl/.

Dubisz, Stanisław, red. Uniwersalny słownik języka polskiego PWN. Warszawa: Wydawnictwo Naukowe PWN, 2008 (wersja elektroniczna CD).

Dyszak, Andrzej S. „Kochankowie ze Stawiska. Językowy obraz uczuć Jarosława Iwaszkiewicza w jego listach do zmarłego Jurka Błeszyńskiego". W: (Nie)męskość w tekstach kultury XIX-XXI wieku, red. Barbara Zwolińska, Krystian Maciej Tomala. Gdańsk: Wydawnictwo UG, 2019, 408-421.

Iwaszkiewicz, Jarosław. Dzienniki 1911-1955. Warszawa: Czytelnik, 2010.

Iwaszkiewicz, Jarosław. Dzienniki 1956-1963. Warszawa: Czytelnik, 2010.

Kochanowski, Jan. Treny. Warszawa: Państwowy Instytut Wydawniczy, 1975.

Kopaliński, Władysław. Słownik mitów i tradycji kultury. Warszawa: Państwowy Instytut Wydawniczy, 1985.

153 Król, Wszystko jak chcesz, 465.

154 Tamże, 472. Wskazany tu fakt Iwaszkiewicz opisuje też w Dziennikach 1956-1963: „Był nagi, oczy miał półotwarte, usta otwarte. [...] Zamknąlem mu powieki. Ustąpiły łatwo”, 331. Użyty w obu cytatach zwrot, zgodnie z definicją jego znaczenia w SJPD, można wszakże rozumieć dwojako: dosłownie i przenośnie, por. zamknąć - zamykać 1. fraz. Zamknąć komuś oczy, powieki «przysłonić zmarłemu otwarte po śmierci oczy powiekami; być przy kim w ostatniej chwili życia». Pisarz przy zgonie Błeszyńskiego nie był obecny.

${ }^{155}$ Król, Wszystko jak chcesz, 490. Chodzi tu o tzw. czuwanie przy zmarłym przed jego pogrzebem. W SJPD nie odnotowano odpowiednich związków z czasownikiem czuwać. Przykład takiego jego użycia można znaleźć w USJP pod hasłem umarly, umarła, por. Czuwać przy umarłej.

156 Król, Wszystko jak chcesz, 478.

157 Tamże, 506. 
Kopaliński, Władysław. Stownik symboli. Warszawa: Wiedza Powszechna, 1990.

Piotrowski, Grzegorz. „Nowa miłość Starego. Jarosław Iwaszkiewicz - Jerzy Błeszyński”. W: Lektury ptci. Polskie (kon)teksty, red. Mieczysław Dąbrowski. Warszawa: Elipsa Dom Wydawniczy i Handlowy Włodzimierz Ulicki, 2008, 244-261.

Skubalanka, Teresa. Wprowadzenie do gramatyki stylistycznej języka polskiego. Lublin: Wydawnictwo Uniwersytetu Marii Curie-Skłodowskiej, 2000.

Warkocki, Błażej. Różowy język. Warszawa 2013.

\section{Językowe środki neutralizacji śmierci w listach Jarosława Iwaszkiewicza do zmarłego Jerzego Błeszyńskiego}

Streszczenie

Przedmiotem analizy w niniejszym artykule są listy Jarosława Iwaszkiewicza do zmarłego kochanka, Jerzego Błeszyńskiego, a celem opisu stał się sposób „mówienia” autora tych tekstów o śmierci ich adresata w celu jej zneutralizowania, tj. osłabienia jej wpływu na życie pisarza i/lub zniesienia opozycji między śmiercią (zaistniałym faktem) a życiem (w wykreowanym świecie listów). Artykuł sytuuje się w zakresie badań wykorzystujących metodologię gramatyki stylistycznej, a zawarte w nim rozważania dotyczą zjawisk semantycznych i sposobu ich formalnojęzykowej kreacji.

Iwaszkiewicz wykorzystał motyw niedoszłego wyjazdu Błeszyńskiego do Surabai w Indonezji do zastąpienia nim - w całym analizowanym zbiorze „listów pośmiertnych” - mówienia o śmierci ukochanego. Obok konsekwentnego jej kryptonimowania za pomocą wyrazów, wyrażeń i zwrotów z leksykalnego pola podróży pojawiają się też w analizowanych listach językowe wykładniki konceptualizacji śmierci jako nieobecności i oddalenia bliskiej osoby. W dwóch listach pisarz mówi o śmierci Błeszyńskiego w kategorii snu. Chcąc uniknąć bezpośredniego mówienia o tym tragicznym zdarzeniu, autor „listów pośmiertnych” używa także nielicznych eufemizmów.

W zachowanych listach Iwaszkiewicza pojawiają się wszakże różne językowe tropy śmierci bliskiej mu osoby. Wyrazy świadomości faktu, że Błeszyński odszedł na zawsze, przeplatają się $\mathrm{z}$ wyrazami niewiary w ten smutny fakt.

\section{Linguistic means of neutralising death in the letters written by Jarosław Iwaszkiewicz and addressed to late Jerzy Błeszyński}

\section{Su m m ary}

The article contains an analysis of the letters written by Jarosław Iwaszkiewicz and addressed to his late lover Jerzy Błeszyński, and depicts the manner of 'talking' of the author of the letters about the addressee's death so that it can be neutralised, i.e. its impact on the life of the writer will be weakened and/or the opposition between death (a fact that took place) and life (in the imagined world of the letters) will be abolished. The article may be placed in the sphere of research based on the method of stylistic grammar, and it deals with the questions that concern semantic phenomena and the manner of their formal-language creation.

Iwaszkiewicz used the motif of the trip that never happened of Błeszyński to Surubai, Indonesia, to replace with it mentions of his lover's death in the whole collection of the 'posthumous letters'. 
In addition to coding it - the death - with words and expressions taken from the lexical field of travelling in the analysed text there are linguistic exponents of conceptualisation of death as an absence and separation of the dead person. In two letters Iwaszkiewicz refers to the death of Błeszyński as a dream. In order to avoid talking directly about death the author of the 'posthumous letters' uses a few euphemisms.

However, in Iwaszkiewicz's letters there appear various linguistic tracks of a death of a person he was close to. He is aware of the fact that Błeszyński left for good, and at the same time he cannot believe it.

\section{Cytowanie}

Dyszak, Andrzej S. Językowe środki neutralizacji śmierci w listach Jarosława Iwaszkiewicza do zmarłego Jerzego Błeszyńskiego. Studia Językoznawcze. Synchroniczne i diachroniczne aspekty badań polszczyzny 18 (2019): 55-74. DOI: 10.18276/sj.2019.18-05. 